\title{
THE FIRST RECORD OF LARVAE OF THE GIANT CRAB PSEUDOCARCINUS GIGAS IN THE PLANKTON
}

\author{
by Caleb Gardner
}

(with one table)

\begin{abstract}
Gardner, C., 1998 (31:xii): The first record of larvae of the giant crab Pseudocarcinus gigas in the plankton. Pap. Proc. R. Soc Tasm. 132: 47-48. https://doi.org/10.26749/rstpp.132.47 ISSN 0080-4703. Tasmanian Aquaculture and Fisheries Institute, GPO Box 252-49, Hobart, Tasmania,Australia 7001.
\end{abstract}

This note reports the first collection of Pseudocarcinus gigas zoeas from the plankton. Plankton samples were collected in November 1992 from oceanic waters on the edge of the continental slope near Pedra Branca, southern Tasmania (longitude $147^{\circ} 09^{\prime} 32^{\prime \prime} \mathrm{E}$ to $147^{\circ} 28^{\prime} 30^{\prime \prime} \mathrm{E}$, latirude $44^{\circ} 11^{\prime} 23^{\prime \prime S}$ to $44^{\circ} 12^{\prime} 30^{\prime \prime} \mathrm{S}$ ). Although samples were collected during the period when $P$. gigas larvae would be expected to be abundant, only three stage- 2 P. gigas zoeas were captured from a total of 342 Brachyuran larvae. All three zoeas were captured in the upper $100 \mathrm{~m}$ of water and were from different samples taken during both day and night.

Keywords: plankton, zoeas, Pseudocarcinus gigas.

\section{INTRODUCTION}

Giant crabs are the basis of a small, high-value fishery in Tasmania, which developed in 1991, mainly around the northeast and northwest of the State. An important aspect of the biology of the species for management is the larval development which influences dispersal and, thus, likelihood of local depletion. Although several laboratory studies have been conducted on the larvae of the giant crab, no larvae or recently settled juveniles have been collected from the wild. Observations on natural distribution are clearly important for validating laboratory studies on vertical migration behaviour (Gardner 1996).

\section{METHODS}

Plankton samples were collected from oceanic waters in the vicinity of Pedra Branca off southern Tasmania (within the region, longitude $147^{\circ} 09^{\prime} 32^{\prime \prime} \mathrm{E}$ to $147^{\circ} 28^{\prime} 30^{\prime \prime} \mathrm{E}$, latitude $44^{\circ} 11^{\prime} 23^{\prime \prime} S$ to $44^{\circ} 12^{\prime} 30^{\prime \prime} \mathrm{S}$ ) in November 1992 . This location is at the southern limit of the range of $P$. gigas, which extends from southern Western Australia to southern New South Wales (McNeill 1920). Based on thecatch rates of commercial fishers (Gardner 1998), there appears to be low abundance of adult giant crabs in southern Tasmania relative to more northern areas.

Samples were collected near the edge of the continental shelf, which is where the fishery is based and, also, where larval release is thought to occur (Levings et al. 1996). The timing of sampling coincided with the period when larvae would be expected to be in the water column, as hatching occurs in October and November (Gardner 1996). Larval development of $P$. gigas in the laboratory is relatively long, with an average duration of 92 days through five zoeal stages and a megalopa to crab 1. (Gardner \& Quintana 1998).

Brachyuran larvae were collected in plankton tows at ten sampling depths, from 10 to $900 \mathrm{~m}$, collected at nine periods over 48 hours. Different depths were sampled in a continuous tow using an EZ plankton net $\left(1 \mathrm{~m}^{2}\right.$ mouth) deployed from the CSIRO's FRV Southern Surveyor (modified 'Tucker trawl, see Harding et al. 1987). Bottom depth ranged from 965 to $1584 \mathrm{~m}$ and sampling of plankton tows was at $100 \mathrm{~m}$ intervals, from 10 to $900 \mathrm{~m}$ depth. The volume of water filtered at each sampling depth ranged between 1650 and $550 \mathrm{~m}^{3}$ and averaged $1140 \mathrm{~m}^{3}$. Sampling was conducted almost continually over 14 and 15 November 1992.

Counts of Brachyuran larvae include both zoeas and megalopas. Only higher Brachyuran larvae were sorted from plankton samples, so counts for total Brachyura probably exclude larvae of crabs from the families Homolidae and Dromidae, both of which occur in the region, as they form bycatch from giant crab traps.

\section{RESULTS AND DISCUSSION}

A total of 342 Brachyuran larvae were collected and, of these, only three were identified as Pseudocarcinus gigas. Identification was based on form of the telson, presence of a dorsal spine on the first abdominal somite, and on the setation patterns of the maxillule and maxillae (full description given in Gardner\& Quintana 1998).

All three $P$. gigas larvae were at the second of the five zoeal stages and were found in the upper $100 \mathrm{~m}$ (table 1). This depth was also where most of the other brachyuran zoeas were collected. Although few specimens of $P$. gigas were collected, their distribution supports laboratory

TABLE 1

Details of Pseudocarcinus gigas zoeas collected in plankton trawls near Pedra Branca on 14-15 November 1992

\begin{tabular}{lcccc}
\hline $\begin{array}{l}\text { Specimen } \\
\text { number }\end{array}$ & $\begin{array}{c}\text { Sample } \\
\text { time } \\
(24 \mathrm{hr} \\
\text { clock })\end{array}$ & $\begin{array}{c}\text { Sample } \\
\text { depth } \\
(\mathrm{m})\end{array}$ & $\begin{array}{c}\text { Mean } \\
\text { temp. } \\
\left({ }^{\circ} \mathrm{C}\right)\end{array}$ & $\begin{array}{c}\text { Density of total } \\
\text { Brachyuran larvae } \\
\left(\text { larvae } / 1000 \mathrm{~m}^{3}\right)\end{array}$ \\
\hline 1 & $2.17-4.37$ & $10-100$ & 12.5 & 161 \\
2 & $7.09-9.12$ & $10-100$ & 12.5 & 48 \\
3 & $16.01-18.55$ & $10-100$ & 12.0 & 80 \\
\hline
\end{tabular}


observations on the response of $P$. gigas larvae to light, pressure, gravity, currents and temperature. This research predicted that early stage zoeas would be found near the surface at all times of the day, unless temperature exceeded $16.2^{\circ} \mathrm{C}$ (Gardner 1996, and unpublished data on behavioural response to temperature).

Brachyuran larvae were distributed predominantly in the surface waters, above $100 \mathrm{~m}$, and this distribution did not appear to be affected by time of sampling (approximately $98 \%$ of zoeas captured were in the $10-100 \mathrm{~m}$ sample). No diel vertical migration cycles were apparent although this may have been due to the low resolution of samples with grouping of zoeas from the upper $100 \mathrm{~m}$. Only one sample appeared to have a different pattern of larval distribution, with most brachyuran larvae at $>800 \mathrm{~m}$ (midday sample: $11.34-14.30 \mathrm{~h}$ : four zoeas in $10-100 \mathrm{~m}$; ten zoeas in 800 $900 \mathrm{~m}$ ). The presence of zoeas at this depth is rare (Rice 1979), although very few larvae were captured in these tows $(\mathrm{n}=14)$, so the unusual depth distribution may be spurious. Temperature declined steadily with depth and there were no indications of thermoclines which may influence larval distribution (McConnaughey \& Sulkin 1984).

The presence of very few $P$. gigas larvae in samples is probably due to the southern latitude of the sampling program. Hatching should have occurred prior to the sampling and the presence of stage- 2 zoeas also suggests that the plankton sampling was after the peak period of hatch. The duration of the zoeal stages in the laboratory is around 50 days (Gardner \& Northam 1997), which indicates that the more benthic megalopa stage would not be found before late December. Consequently, the low capture rate of $P$. gigas zoeas may have been due to limited larval supply at this southerly latitude, although it is also possible that larvae released from this region had been dispersed by currents prior to sampling.

\section{ACKNOWLEDGEMENTS}

Erica Aheimer, Andrew Trotter and Josephine Walker provided valuable assistance in sorting and classifying plankton samples. Samples were obtained from the CSIRO with help from Mark Lewis and Dr Barry Bruce. Assistance in the preparation of this manuscript was provided by Dr Greg Maguire. Financial support and facilities were provided by the University of Tasmania and the Tasmanian Department of Primary Industry and Fisheries.

\section{REFERENCES}

GARDNER, N.C., 1996: Behavioural basis of depth regulation in the first zoeal stage of the giant crab (Pseudocarcinus gigas, Brachyura, Xanthoidea, Oziidae). $H I G H$ LATITUDE CRABS: BIOLOGY, MANAGEMENT AND ECONOMICS. Alaska Sea Grant College Program Rep. 96-02. University of Alaska, Fairbanks: 229-253.

GARDNER, C., 1998: The Tasmanian giant crab fishery: a synopsis of biological and fisheries information. Tasm. Dep. Primary Ind. Fish., Int. Rep. 43: 40 pp.

Gardner, C. \& Northam, M., 1997: Use of prophylactic treatments for larval rearing of giant crabs Pseudocarcinus gigas (Lamarck). Aquaculture 158: 203-214.

Gardner, C. \& Quintana, R., 1998: Larval development of the Australian giant crab Pseudocarcinus gigas (Lamarck 1818) (Decapoda: Oziidae) reared in the laboratory. J. Plank. Res. 20(6): 1169-1188

Harding, G.C., Pringle, J.D., Vass, W.P., Pearre, S. Jr \& Smith, S.J., 1987: Vertical distribution and daily movements of larval lobsters Homarus americanus over Browns Bank, Nova Scotia. Mar. Ecol. Prog. Ser. 41:2941.

Levings, A., Mitchell, B.D., Heeren, T., Austin, C. \& Matheson, J., 1996: Fisheries biology of the giant crab (Pseudocarcinas gigas, Brachyura, Oziidae) in Southern Australia. HIGH LATITUDE CRABS: BIOLOGY, MANAGEMENT AND ECONOMICS. Alaska Sea Grant College Program Rep. 96-02. University of Alaska, Fairbanks: 125-151.

McConnaughey, R.A. \& Sulkin, S.D., 1984: Measuring the effects of thermoclines on the vertical migration of larvae of Callinectes sapidus (Brachyura: Portunidae) in the laboratory. Mar. Biol. 81(2): 139-145.

MCNeILL, F.A., 1920: Studies in Australian carcinology, no. 1. Rec. Aust. Mus. 13: 108-109.

RiCE, A.L., 1979: A remarkable benthic catch of Portunid crab zoeae (Decapoda, Brachyura). Crustaceana Supp. 5: 1721.

(accepted 28 September 1998) 